\title{
DID THE 2008 GLOBAL ECONOMIC CRISIS AFFECT LARGE FIRMS IN EUROPE?
}

Piotr Raźniak, Anna Winiarczyk-Raźniak

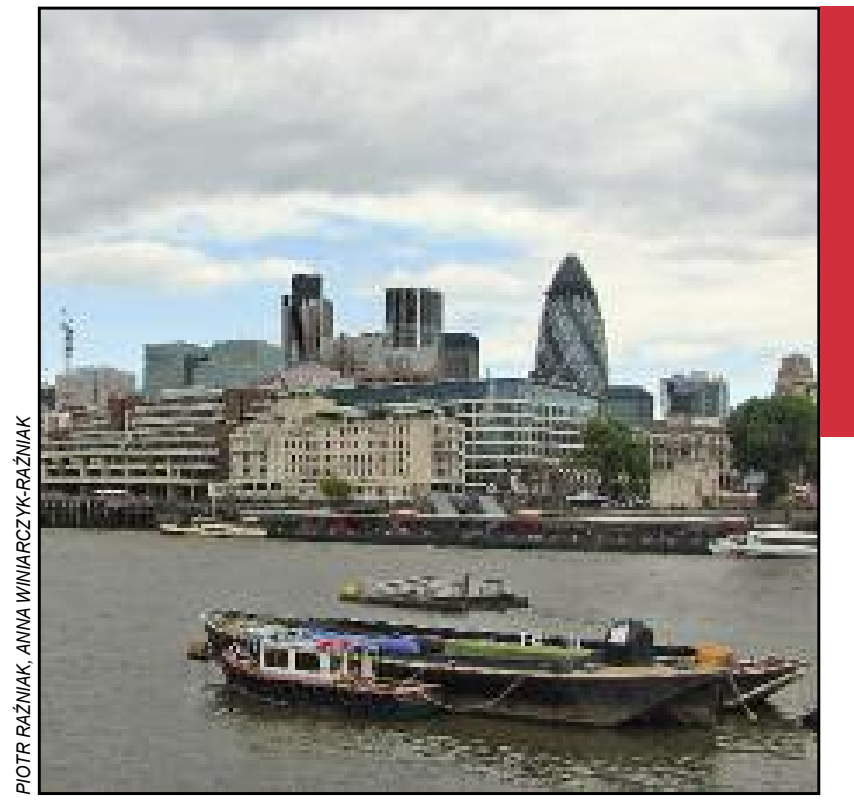

City of London. 


\section{Did the 2008 global economic crisis affect large firms in Europe?}

DOI: http://dx.doi.org/10.3986/AGS.740

UDC: $911.3: 338.124 .4(100)$

COBISS: 1.01

ABSTRACT: The paper analyses the spatial distribution of the largest global corporations found on the Forbes Global 2000 list and with headquarters in Europe. The analysis includes the effects of the 2008 global financial crisis on changes in corporate financial performance. Research has shown that London has the largest economic potential in Europe, while companies in Central and Eastern European cities exhibit high rates of growth. The crisis triggered a decentralisation of corporate headquarters' location resulting in more cities with corporate headquarters.

KEY WORDS: geography, globalization, economic crisis, corporations, cities, Forbes Global 2000

The article was submitted for publication on February $19^{\text {th }}, 2014$.

Piotr Raźniak, Ph. D.

Institute of Geography, Pedagogic University in Kraków

U. Podchorążych 2, 30-084 Kraków, Poland

E-mail:prazniak@up.krakow.pl

Anna Winiarczyk-Raźniak, Ph. D.

Institute of Geography, Pedagogic University in Kraków

U. Podchorążych 2, 30-084 Kraków, Poland

E-mail: arazniak@up.krakow.pl 


\section{Introduction}

Large affluent cities create easy access to information, which makes it easier for specialists and scientists to work together. Such cities also create the optimal living conditions for corporate elites in terms of income, social interaction, and cultural offerings. Cities are home to the headquarters of international corporations as well political institutions, media outlets, and progressive centres of the production and "consumption « of cultural offerings. Large corporations have the opportunity to concentrate in cities, which results in innovative synergies (Ravbar, Bole and Nared 2005). Corporations help drive the growth of the central city as well as its suburbs by attracting qualified workers and specialists from around the world (Beaverstock and Boardwell 2000). Large corporations play a key role in accelerating the establishment of international linkages and shaping cities as centres of global activity. Another area of corporate-driven growth is the development of a knowledge-based economy (Dorocki and Borowiec 2012; Rachwał 2013), which helps accelerate globalisation (Pain 2008). It is worth noting that economic recession is not the only factor affecting corporate performance (Rachwał and Boguś 2012). Globalised economic processes are becoming a key driver of growth and decline today.

Globalisation and its associated corporate location factors and their increasing importance (Płaziak and Szymańska 2014) as well as the development of new management practices (Szymańska 2012) became ever more relevant in the 1990s (Beaverstock, Smith and Taylor 1999). Linkages between large cities increased and manifested themselves via the establishment of daughter units in countries without corporate headquarters. Globalisation also triggered a change in spatial management, both on a regional and global scale (Lüthi, Thierstein and Goebel 2010). The process of globalisation accelerated rapidly in the years that followed, with the formation of global corporations valued at more than 20 billion USD (Zioło 2006). Key elements of globalisation include corporate expansion via the acquisition of other companies and the relocation of business activity to countries with lower labour costs (Kilar 2009b). Global corporations establish sales offices in foreign countries, which strengthen trade linkages between host cities. In turn, this leads to a growing significance of BRIC nations and other emerging markets (Liu, Derudder and Taylor 2014). This includes Central and Eastern Europe following its transition from communism to capitalism in the early 1990s, which helped spark an investment boom in the region (Ravbar 2009; Lorber 1999). The region now hosts an increasing number of world-class companies, which serve as harbingers of the world economy. This led to a relative decline of the significance of the United States, although it remains the world's most powerful economy (Csomós 2013a; Wilczyński and Wilczyński 2011).

Many researchers attempt to create typologies of cities based on a variety of social and economic indicators. Nelson (1955) analysed and classified 897 American cities based on business activity and employment in different sectors. He established ten city types. O. D. Duncan (1960) classified cities based on their spatial impact and principal function. M. Paccione (2001) classified American metropolitan areas based on four principal functions:

- multifunctional,

- service oriented,

- production oriented,

- consumer oriented.

Paccione also created sub-types for each of the four principal types. Goe and Shanahan (1991) investigated the role of industry in the urban economy in order to assess the significance of a city. Krätke (2007) focused on the effect of the high-tech industry in strengthening a city's economy.

A key concept in this field of research is that of the world city, which is designed to help assess the significance of international linkages between cities (Hall 1966). The world city concept was further developed in the 1980s and 1990s (Friedmann 1986, 1995). Today, advanced research on this subject is performed by researchers part of the Globalization and World Cities network (Internet 3). This group of researchers investigates linkages between large corporations in the area of accountancy, advertising, management consultancy, financial services, and law (Beaverstock, Smith and Taylor 1999). Analysis of data for 1998 and 2000 has shown London and New York to be the most important global cities (Taylor, Catalano and Walker 2002). Similar results were obtained for 2004 (Taylor and Aranya 2008). The latest data indicate London and New York as the most linked global cities; however, the emergence of certain Asian cities is also becoming apparent (Taylor et al. 2010; Csomós and Derudder 2014). Cities in Central and Eastern Europe are also gaining in significance due to an increasing number of international linkages (Derudder et al. 2010).

The purpose of this paper is to assess spatial differences relative to the effects of the 2008 global financial crisis on the performance of the largest European corporations. 


\section{Methods}

The paper analyses data obtained from the Forbes Global 2000 list for 2006 and 2012 (Internet 2). The list of the 2000 largest public companies in the world is compiled based on four parameters: revenue, profit, assets, market value. The minimum value for each category is as follows: revenue (3.89 bln USD), profit (232.2 $\mathrm{mln}$ USD), assets (7.85 bln USD), market value (4.25 bln USD). A company must fit into at least one of the four categories in order to make the list. Next, the data were aggregated at the city level for cities with corporate headquarters (Csomós 2013b). The data were used to calculate each company's return on sales for each of the studied cities relative to the number of corporate headquarters per city.

In order to make the research more broadly applicable, additional indicators were calculated that present the situation at the country level. Two typologies were created in order to illustrate spatial differences across Europe. The first typology analyses the relationship between changes in revenue and changes in the number of corporate headquarters in selected European countries in the period 2006-2012 (Fig. 3). All corporate data were obtained from the Forbes Global 2000 list. Changes in revenue for European companies were compared to average global changes in revenue for the period 2006-2012 (+50\%). The purpose of this step was to show how revenues of European companies fare against those of companies around the world. Five types of cities were identified:

- type 1 is characterised by a revenue growth rate below the world average and a decrease in the number of corporate headquarters,

- type 2 is characterised by a revenue growth rate below the world average and stability in the number of corporate headquarters,

- type 3 is characterised by a revenue growth rate above the world average and a decrease in the number of corporate headquarters,

- type 4 is characterised by a revenue growth rate above the world average and stability in the number of corporate headquarters,

- type 5 is characterised by a revenue growth rate above the world average and an increase in the number of corporate headquarters.

A second typology was created in order to evaluate the effects of the 2008 global financial crisis on European economies. This typology is based on the profit and revenues of Forbes Global 2000 companies headquartered in Europe in 2006-2012 (Figure 4). Two boundary values were used to assess European companies in terms of profit growth rates $(+61.8 \%)$ and revenue growth rates $(+50 \%)$. Both boundary values were calculated for all Forbes Global 2000 companies and represent averages. This comparison evaluates European Forbes companies relative to all Forbes companies. The following six types of cities were identified:

- type 1 is characterised by decreasing profit growth rates and increasing revenue growth rates below the world average,

- type 2 is characterised by decreasing profit growth rates and increasing revenue growth rates above the world average,

- type 3 is characterised by increasing profit growth rates and increasing revenue growth rates below the world average,

- type 4 is characterised by increasing profit growth rates below the world average and increasing revenue growth rates above the world average,

- type 5 is characterised by increasing profit growth rates above the world average and increasing revenue growth rates below the world average,

- type 6 is characterised by increasing profit growth rates and increasing revenue growth rates above the world average.

The analysis included all cities in Europe and the European part of Russia.

\section{Results}

\subsection{Number of corporate headquarters per city}

The largest number of corporate headquarters associated with European companies listed by Forbes Global 2000 were found in London (89) and Paris (65). Both are considered leading globally linked cities 
(Taylor et al. 2010; Raźniak 2013; Raźniak and Winiarczyk-Raźniak 2013). London and Paris lead Europe in terms of the number of corporate headquarters, with Stockholm and Madrid far behind with 23 and 28 headquarters, respectively (Figure 1). The part of Europe leading the continent in terms of the number of corporate headquarters is the central part of Western Europe stretching from London to Paris to Milan and Western Germany. This part of Europe is home to the vast majority of the largest European corporations and is known by its pentagonal shape (Kincses, Nagy and Tóth 2013). This pentagonal region generates about $50 \%$ of the GDP of the European Union and includes $40 \%$ of its residents, but only $20 \%$ of its area (ESPON Atlas 2006). This European region is characterised by strong links between cities, most likely due to the presence of a large number of corporate headquarters and sales offices of global corporations (Allen 2008; Wall and Knap van den 2011). The region also enjoys a very high rate of investment

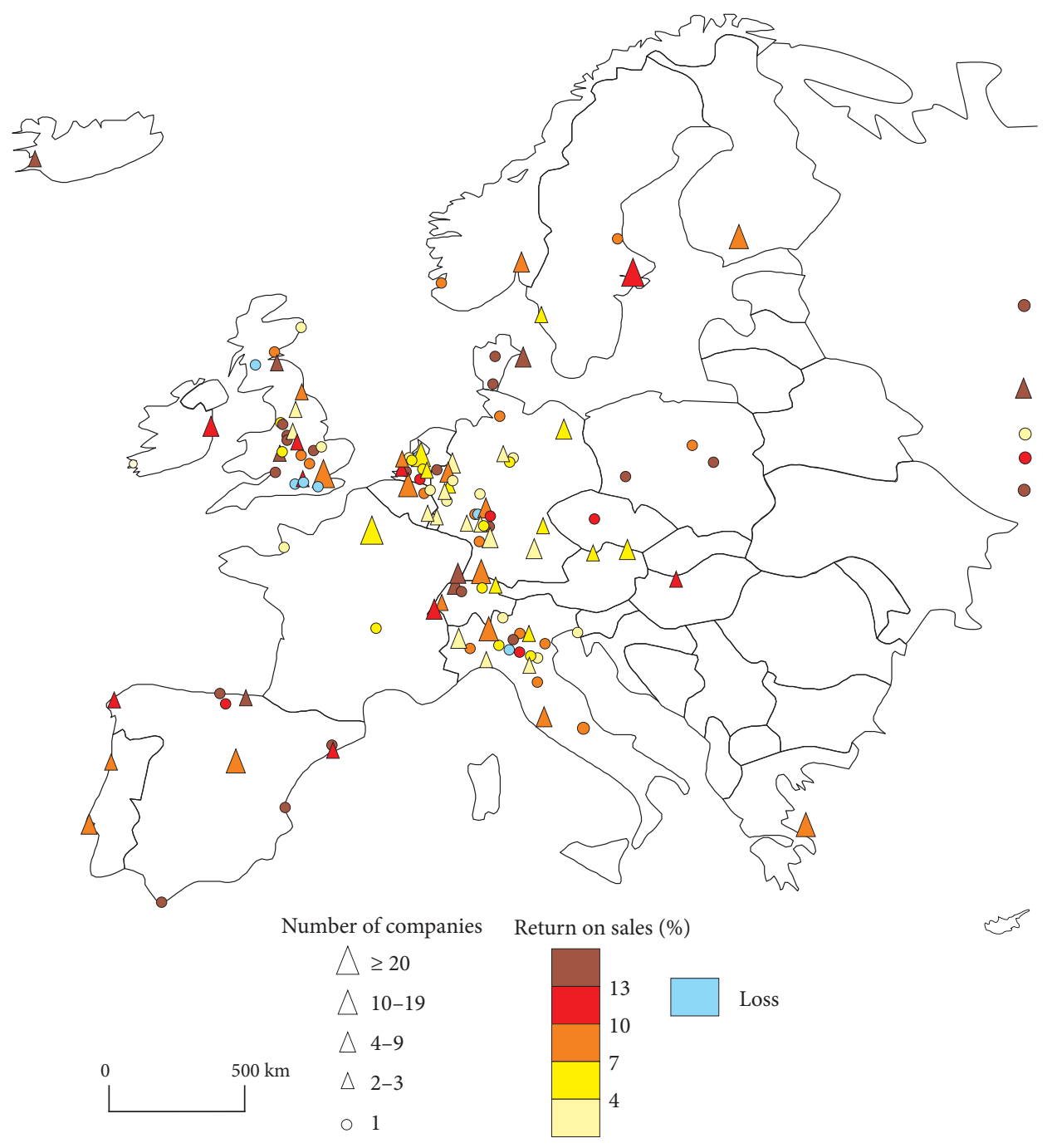

Figure 1: Return on sales of the largest European companies versus the number of the largest European companies per city in 2006, as listed by Forbes Global 2000 (Source: Author's own work based on Forbes Global 2000, Globalization and World Cities). 
(Burger, Knaap van der and Wall 2013). On the other hand, Central and Eastern Europe possesses far fewer corporate headquarters. Three cities in Poland are home to one corporate headquarters each. Thirteen corporations are headquartered in five cities in Russia. Finally, one city in Hungary is home to two corporate headquarters and one city in the Czech Republic is home to one corporate headquarters.

The number of corporate headquarters decreased in 2012 in the largest European cities (Figure 2). This pattern held true in London, with 21 fewer companies on the Forbes Global 2000 list between 2006 and 2012. Paris also lost the headquarters of five companies. On the other hand, the number of corporate headquarters in Moscow increased rapidly from eight in 2006 to twenty in 2012. The energy sector (Taylor and Csomós 2012) and the financial sector (Agibetova and Samson 2008) in Moscow are growing rapidly. In addition, the two sectors are much less dominated by foreign corporations than in other countries in Central and Eastern Europe (Karreman 2009).

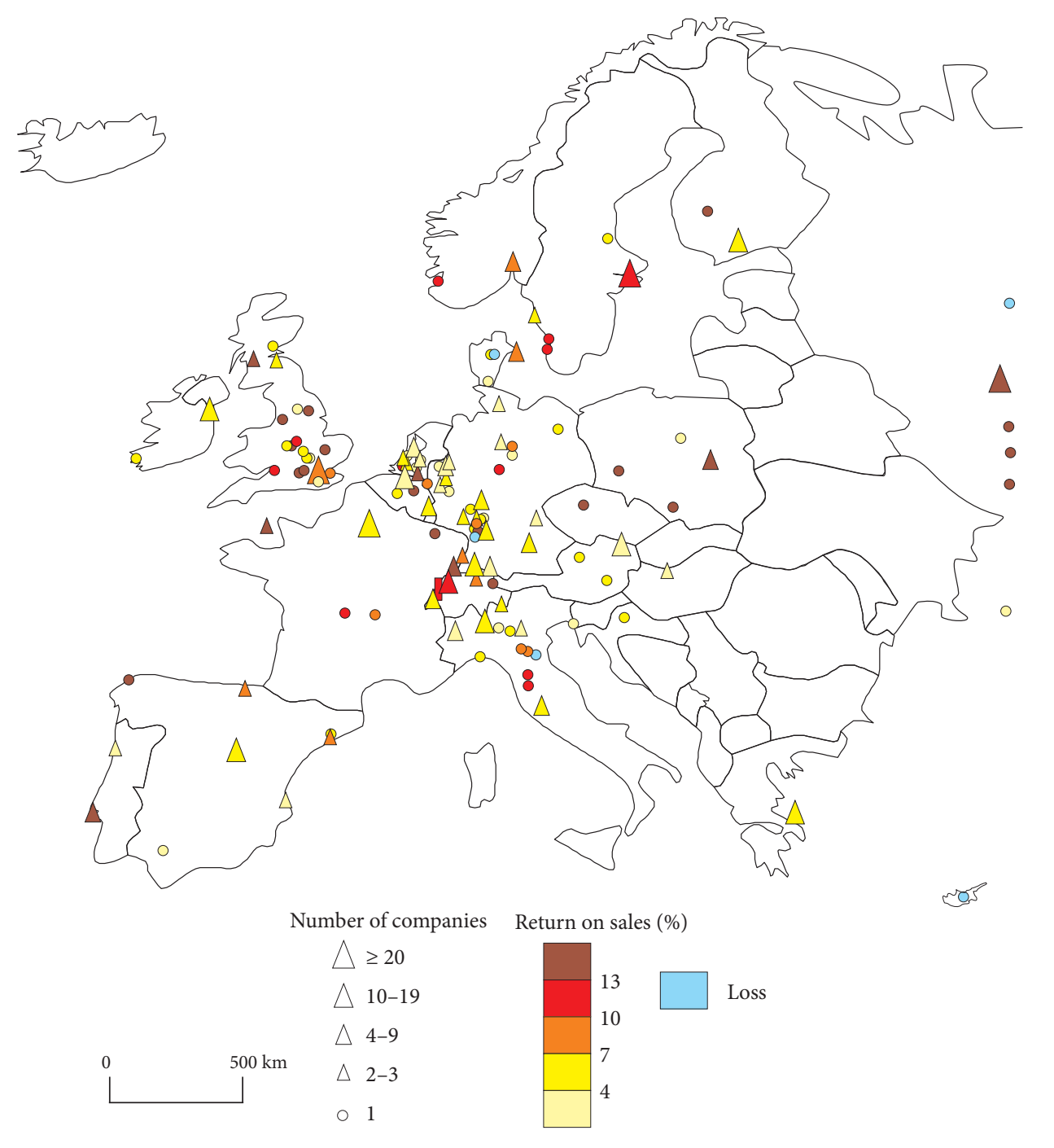

Figure 2: Return on sales of the largest European companies versus the number of the largest European companies per city in 2012, as listed by Forbes Global 2000 (Source: Author's own work based on Forbes Global 2000, Globalization and World (ities). 
The number of Polish corporations is also increasing on the Forbes Global 2000 list. This is especially true in Warsaw where the number of Forbes corporations increased from one to four during the study period. In France, the city with the largest number of corporate headquarters is Paris. Only two Forbes corporations were found outside of Paris in 2006 (Clermont-Ferrand and Granville). This pattern held true in 2012, with only three Forbes corporations outside of Paris (Clermont-Ferrand, Limoges and Mets). In other developed countries in Europe, the spatial pattern was more regular. This includes Germany, Switzerland, Holland and Italy. Even in Great Britain, which is dominated by London, 25 Forbes corporations were found outside of London in 2006 and 18 in 2012.

The European cities with the highest return on sales were home to only one Forbes company headquarters (Gibraltar 57.1\%, Lipetsk 39.1\%, Silkeborg 23.7\%). Cities with more than ten Forbes companies had a return on sales of $7 \%$ to $10 \%$. Stockholm had a higher rate of return at $12.4 \%$. Amsterdam had a lower rate of return at 5.6\%. High return on sales values were noted for cities in Eastern Europe, especially the Russian cities of Lipetsk (39.1\%) and Cherepovets (21\%).

By 2012 many European companies had experienced the effects of the 2008 global financial crisis (Figure 2). The average rate of return on sales for all Forbes Global 2000 companies headquartered in Europe decreased slightly from $7.09 \%$ in 2006 to $6.92 \%$ in 2012 . The decline was noted primarily in Western Europe, while Central and Eastern Europe continued to maintain a healthy rate of return on sales. Cities with more than ten corporate headquarters were characterised by a rate of return on sales of $4 \%$ to $7 \%$ in 2012 , which was a decline from 2006 (7\% to 10\%) (Figure 1). A higher rate of return on sales was noted for London, Stockholm, and the rapidly globalising Moscow (Raźniak 2014). High rates of return on sales were also posted by Polish companies in the mining sector including KGHM Polska Miedź S. A., with a very high rate of return on sales of 50.1\% in 2012. Another Polish mining company, Jastrzębska Spółka Węglowa, also enjoyed a high rate of $22.2 \%$ (Sitek et al. 2013). Jastrzębska Spółka Węglowa is one of the largest employers in southern Poland with 29,500 workers (Kłosowski et al. 2013). A high rate of return on sales was also noted by companies in Warsaw, which may help increase economic security in the city (Raźniak and Winiarczyk-Raźniak 2014) and may help attract qualified workers from across Poland (Winiarczyk-Raźniak and Raźniak 2012). Warsaw's higher standard of living in terms of income and access to services provided by the city's government may also help attract investors to the city (Winiarczyk-Raźniak and Raźniak 2011). The weaker performance of cities with a large number of corporate headquarters may result from the diversity of corporations present, as those with superb performance may by offset to some extent by those with weaker financial results including losses. The opposite is also true. Cities with only one Forbes company experienced weak financial performance when that one company experienced weak financial performance and could not be offset by the strong performance of other companies.

London and Paris dominate Europe in terms of the number of corporate headquarters of Forbes Global 2000 companies. However, the economic significance of London and Paris decreased as a result of the 2008 global financial crisis. On the other hand, the number of Forbes corporations in Eastern Europe increased during the same time period, as did the rate of return of sales relative to Western Europe.

\subsection{Company typologies based on selected parameters}

As many as eight countries were classified as Type 1 (the weakest). All eight were affluent nations in Western Europe (Figure 3). Belgium and Norway were classified as Type 2, which is a partly weak type. Both countries are also affluent. Type 5 or the most positive type was noted for just a few countries in Western Europe including Switzerland, Austria, Luxembourg, and Ireland. Type 4 or one of the more positive types was noted for Hungary and the Czech Republic in Central Europe. The strongest type (5) was noted for Poland and Russia. Reasons for this may include economic recession in Western Europe and economic growth in Central and Eastern Europe due to lower labour costs that attract investment. This may help explain the general predominance of positive types in Eastern Europe and the predominance of negative types in Western Europe.

The weakest type, Type 1, includes Holland, Denmark and as well as Italy, a country strongly affected by the 2008 global financial crisis (Figure 4). Type 2, characterised by decreasing profits and small revenues, includes Greece and Hungary, both of which were strongly affected by the 2008 global financial crisis and experienced a decrease in GDP. Type 2 also includes Luxembourg, which has the largest GDP per capita 
in Europe (Internet 1). Luxembourg experienced a small decline in profits, but remains highly attractive to global corporations characterised by very high revenue growth rates.

Overall, the most common types in Western Europe were Types 3 and 4. While the strongest economies in Europe are characterised by Forbes companies with increasing profits and revenues below world average, Forbes companies in other regions of the world enjoy even higher profits and revenues. Type 5 is only represented by Norway. Type 6 , the most positive of the types identified and characterized
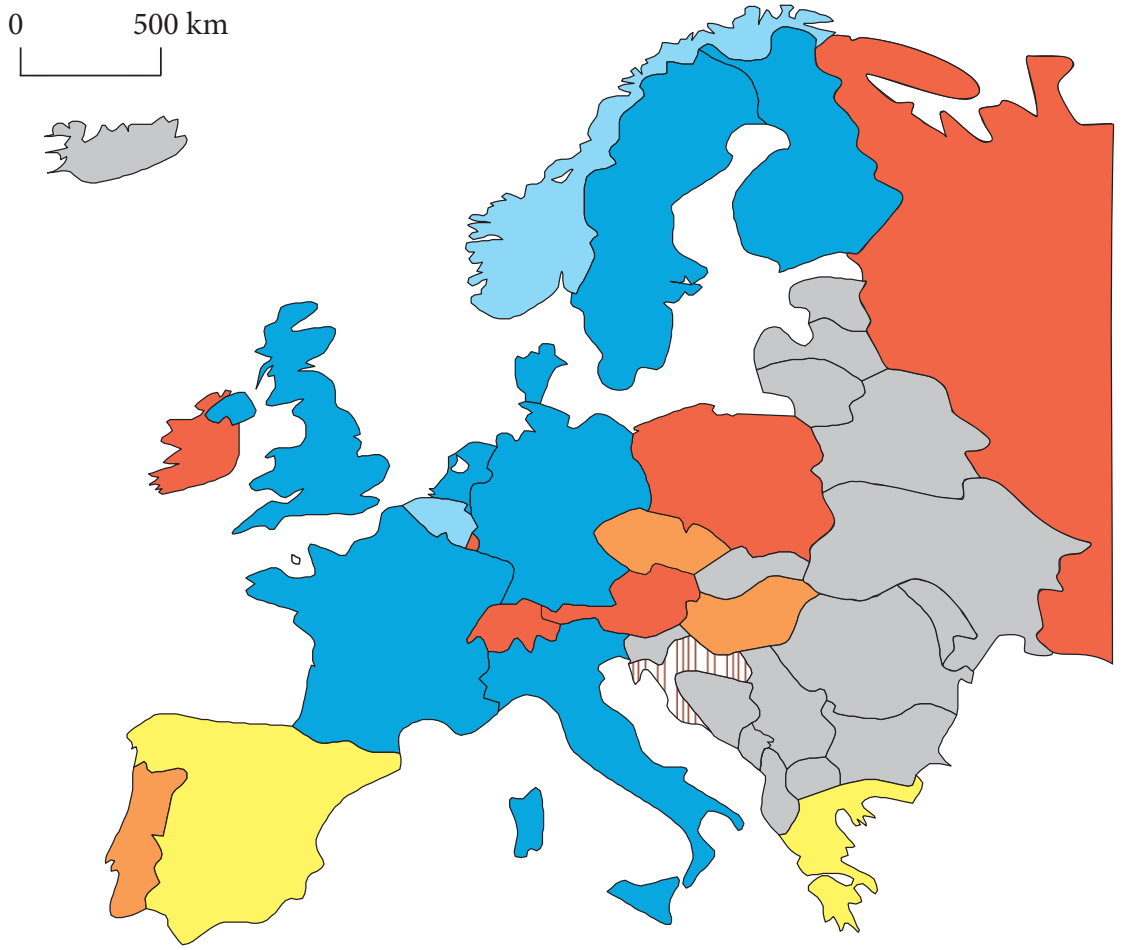

Types of countries:

$\square$ Revenue growth rate below the world average and decrease in the number of headquarters Revenue growth rate below the world average and stability in the number of headquarters Revenue growth rate above the world average and decrease in the number of headquarters Revenue growth rate above the world average and stability in the number of headquarters Revenue growth rate above the world average and increase in the number of headquarters Lack of Forbes Global 2000 companies ||⿴囗口) Lack of companies in 2006

Average global revenue growth for Forbes Global 2000 companies in 2006-2012 (+50\%)

Figure 3: Typology of countries based on revenue growth rates and the number of corporate headquarters of the largest European companies in 2006-2012 (Source: Author's own work based on Forbes Global 2000, Globalization and World Cities). 
by growth in the studied parameters exceeding the world average, was noted for countries in Eastern Europe including Poland, Russia, and the Czech Republic. On the other hand, only Western European countries such as Portugal, Austria, and Ireland include cities classified here as Type 6 with increasing profits and revenues at rates exceeding the world average.

It may be argued that the largest companies in Europe are experiencing profit and revenue growth, but at a rate that is lower than the world average.

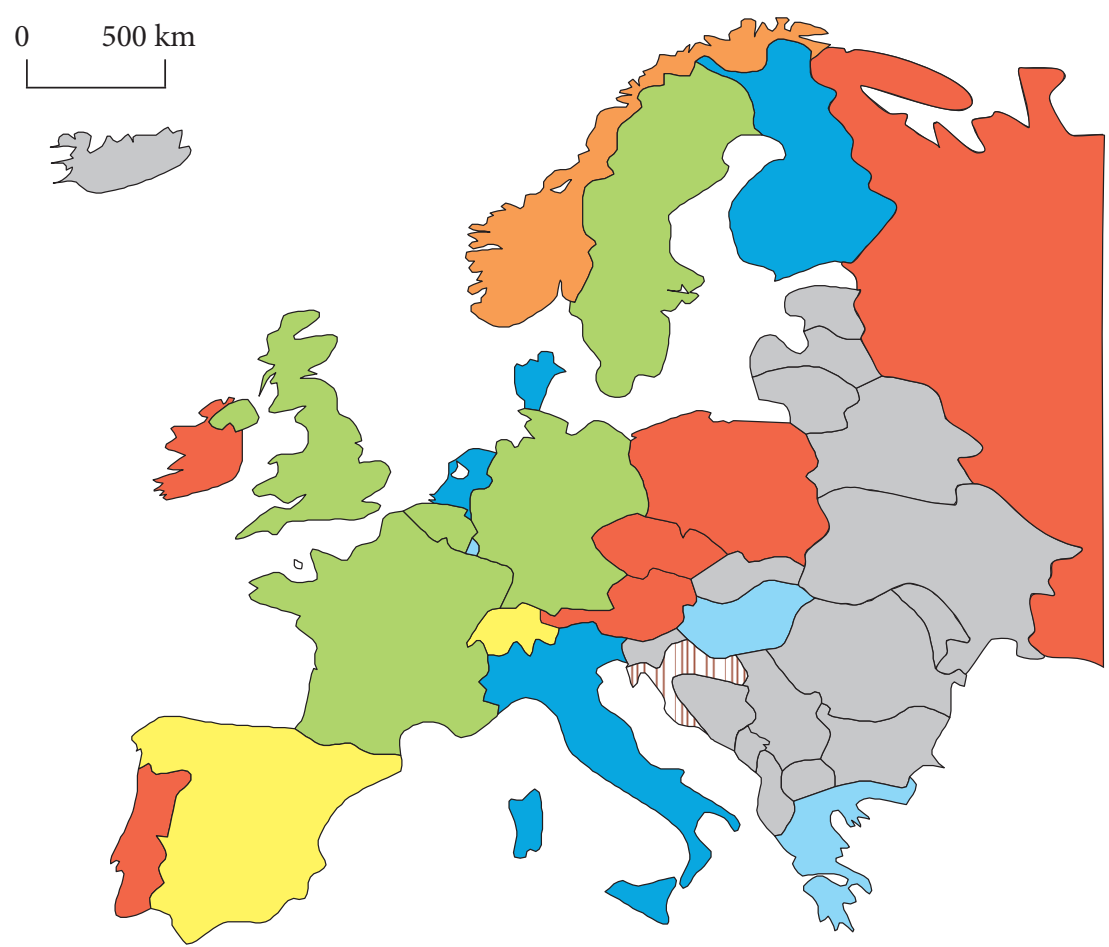

Types of countries:

Decreasing profit and revenue growth below the world average,

Decreasing profit and revenue growth above the world average,

Profit growth below the world average, revenue growth below the world average Profit growth below the world average, revenue growth above the world average Profit growth above the world average, revenue growth below the world average Profit growth above the world average, revenue growth above the world average Lack of Forbes Global 2000 companies

피 Lack of companies in 2006

Average global profit growth for Forbes Global 2000 companies in 2006-2012 (+61.8\%) Average global revenue growth for Forbes Global 2000 companies in 2006-2012 (+50\%)

Figure 4: Typology of countries based on profit growth rates and revenue growth rates for the largest European companies in 2006-2012 (Source: Author's own work based on Forbes Global 2000, Globalization and World (ities). 


\section{Discussion and conclusion}

Both the financial results and the number of corporate headquarters vary significantly between Eastern Europe and Western Europe. Despite the 2008 global financial crisis, London and Paris continue to possess the largest number of Forbes corporations. However, the number of these corporations did decline between 2006 and 2012. Overall, the number of Forbes corporations in the old fifteen member states of the European Union is decreasing, while that in other European countries is increasing. This is especially true of the European part of Russia. It may be argued that Moscow is becoming a key decision centre in Eastern Europe and the world. In addition, the revenues and profits of European companies are increasing at a lower rate than those of non-European companies. This may lead to an overall downgrade of European companies on the world stage. In summary, the 2008 global financial crisis affected mostly the largest companies in Western Europe, while their Eastern European counterparts continued to enjoy higher than average growth rates. Eastern Europe's high growth rates may be explained in part by the region's difficult political history reaching the early 1990s. The politics of the era had severely limited the economic potential of companies in Central and Eastern Europe. This delay in economic development is being offset quite rapidly, especially in the case of Moscow and Warsaw. At the same time, the number of global companies with headquarters in China is increasing rapidly and their financial results are also strong. Many Chinese companies are becoming key players in global markets, which is illustrated by the presence of three Chinese banks in the top three spots on the Forbes list.

\section{References}

Agibetova, U., Samson, I. 2008: The metropolisation of the FSU: temptative measurement via the Method of hyperlinks notoriety. Eurasian integration yearbook 2008. Almaty.

Allen, J. 2010: Powerful city networks: more than connections, less than domination and control. Urban studies 47-13. DOI: http://dx.doi.org/10.1177/0042098010377364

Beaverstock, J. V., Boardwell, J. T. 2000: Negotiating globalization, transnational corporations and global city financial centres in transient migration studies. Applied geography 20-3. DOI: http://dx.doi.org/ 10.1016/S0143-6228(00)00009-6

Beaverstock, J. V., Smith, R. G., Taylor, P. J. 1999: A roster of world cities. Cities 6-6. DOI: http://dx.doi.org/ 10.1016/S0264-2751(99)00042-6

Burger, J. M., Knaap, van der B., Wall, R. S. 2013: Revealed competition for greenfield investment in European regions. Journal of economic geography 13-4. DOI: http://dx.doi.org/10.1093/jeg/lbs024

ESPON Atlas 2006: Mapping the structure of the European territory. European Union.

Csomós, G. 2013a: The command and control centers of the United States 2006/2012: An analysis of industry sectors influencing the position of cities. Geoforum 12-50. DOI: http://dx.doi.org/10.1016/ j.geoforum.2013.09.015

Csomós, G. 2013b: http://www.lboro.ac.uk/gawc/datasets/da26.html

Csomós, G., Derudder, B. 2014: European cities as command and control centres, 2006-2011. European urban and regional studies 21. DOI: http://dx.doi.org/10.1177/0969776412453149 (15.5.2014)

Derudder, B., Taylor, P. J., Ni, P., De Vos, A., Hoyler, M., Hansens, H., Basens, D., Huang, J., Witlox, F., Shen, W., Yang, X. 2010: Pathways of change: shifting connectivities in the world city network, 2000-08. Urban studies 47. DOI: http://dx.doi.org/10.1080/00330124.2013.781488

Dorocki, S. 2013: Regional differentiation in the development of French towns - quantitative analysis. Barometr regionalny 3-29.

Dorocki, S., Borowiec, M. 2012: The process of transformation of academic centres as a factor upgrading the quality of human capital in the regions of France. Bulletin of geography. Socio-economic series 18. DOI: http://dx.doi.org/10.2478/v10089?012?0016?2

Duncan, O. D. 1960: Metropolis and region. Baltimore.

Friedmann, J. 1995: Where we stand: a decade of world city research. World cities in a world-system. Cambridge.

Friedmann, J. 1986: The world city hypothesis, development and change 17. DOI: http://dx.doi.org/10.1111/ j.1467-7660.1986.tb00231 
Goe, R. W., Shanahan, J. L., 1991: Patterns of economic restructuring in industrial-

based metropolitan areas. Urban studies 28-4. doi: 10.1080/00420989120080651

Hall, P. 1966: The World Cities. London. DOI: http://dx.doi.org/10.1080/00420989120080651

Internet 1: www.epp.eurostat.ec.europa.eu (5.2.2015).

Internet 2: www.forbes.com (5.2.2015).

Internet 3: www.lboro.ac.uk (2.10.2014).

Karreman, B., 2009: Financial geographies and emerging markets in Europe. Tijdschrift voor economische en sociale geografie 100-2. DOI: http://dx.doi.org/10.1111/j.1467-9663.2009.00534

Kilar, W. 2009a: Koncentracja przestrzenna światowych firm informatycznych. Prace Komisji geografii przemysłu Polskiego Towarzystwa Geograficznego 12.

Kilar, W. 2009b: Korporacje informatyczne jako element struktury metropolii. Studia Komitetu przestrzennego zagospodarowania kraju PAN 125. Warszawa.

Kincses, Á., Nagy, Z., Tóth, G. 2013: The spatial structures of Europe. Acta geographica Slovenica 53-1. DOI: http://dx.doi.org/10.3986/AGS53103

Kłosowski, F., Pytel, S., Runge, A., Sitek, S., Zuzańska-Żý́ko, E. 2013: Rynek pracy w podregionie rybnickim. Prace Wydziału nauk o Ziemi Uniwersytetu Śląskiego. Sosnowiec.

Krätke, S. 2007: Metropolisation of the European Economic Territory as a Consequence of Increasing specialisation of urban agglomerations in the knowledge economy. European planning studies 15-1. DOI: http://dx.doi.org/10.1080/09654310601016424

Liu, X., Derudder, B., Taylor, P. J. 2014: Mapping the evolution of hierarchical and regional tendencies in the world city network 2000-2010. Computers, environment and urban systems 43. DOI: http://dx.doi.org/ $10.1068 / \mathrm{a} 45488$

Lorber, L. 1999: The economic transition of Slovenia in the process of globalisation. Geografski zbornik 39.

Lüthi, S., Thierstein, A., Goebel, V. 2010: Intra-firm and extra-firm linkages of the knowledge economy The case of the mega-city region of Munich. Global networks 10-1. DOI: http://dx.doi.org/10.1111/ j.1471-0374.2010.00277.x

Nelson, H. J. 1955: A service classification of American cities. Economic geography 31.

Pacione, M. 2001: Urban Geography: a global perspective. London.

Pain, K. 2008: Looking for the 'core' in knowledge globalization: The need for a new research agenda. Globalization and World cities 286.

Płaziak, M., Szymańska, A. I. 2014: Role of modern factors in the process of choosing a location of an enterprise. Procedia - social and behavioral sciences 120. DOI: http://dx.doi.org/10.1016/j.sbspro.2014.02.083

Rachwał, T. 2013: Rola przedsiębiorstw przemysłowych w rozwoju gospodarki opartej na wiedzy. Prace Komisji Geografii Przemysłu Polskiego Towarzystwa Geograficznego 21.

Rachwał, T., Boguś, M. 2012: Konkurencyjność przedsiębiorstw przemysłowych w Polsce w ujęciu regionalnym na tle innych krajów Unii Europejskiej. Przekształcenia struktur regionalnych. Kraków.

Ravbar, M. 2009: Economic geographical assesment of investments - a development factor in regional development. Acta geographica Slovenica 49-1. DOI: http://dx.doi.org/10.3986/AGS49105

Ravbar, M. Bole, D., Nared, J. 2005: A creative milieu and the role of geography in studying the competitiveness of cities: the case of Ljubljana. Acta geographica Slovenica 45-2. DOI: 10.3986/AGS45201

Raźniak, P., Winiarczyk-Raźniak A. 2014: Influence of the societal security level on population migrations in Poland. Procedia - social and behavioral sciences 120. DOI: http://dx.doi.org/10.1016/j.sbspro.2014.02.075

Raźniak, P. 2014: Pozycja gospodarcza polskich miast na arenie międzynarodowej i krajowej. Miasta, aglomeracje, metropolie w nurcie globalnych przemian. Lublin.

Raźniak, P. 2013: Globalne powiązania metropolii europejskich - próba typologii. Studia Miejskie 9.

Raźniak, P., Winiarczyk-Raźniak, A. 2013: Spatial distribution and differences in migration patterns and revenues of gminas in the Kraków Metropolitan area. Bulletin of geography. Socio-economic series 19. DOI: http://dx.doi.org/10.2478/bog-2013-0005

Raźniak, P. 2012: Procesy społeczno - ekonomiczne w Krakowskim Obszarze Metropolitalnym. Prace Geograficzne UJ 129-4. DOI: http://dx.doi.org/10.4467/20833113PG.12.014.0522

Sitek, S., Runge, J., Kłosowski, F., Runge, A., Petryszyn, J., Pytel, S., Spórna, T., Kurpanik, M., Zuzańska-Żyśko, E. 2013: Społeczno-gospodarcze oraz przestrzenne kierunki zmian regionalnego oraz lokalnych rynków pracy województwa śląskiego. Sosnowiec. 
Szymańska, A. I. 2012: Globalizacja a nowe koncepcje zarządzania przedsiębiorstwem. Przedsiębiorczość edukacja 8.

Taylor, P. J., Csomós, G. 2012: Cities as control and command centres: Analysis and interpretation. Cities 29-6. DOI: http://dx.doi.org/10.1016/j.cities.2011.09.005

Taylor, P. J., Ni, P., Derudder, B., Hoyler, M., Huang, J., Lu, F., Pain, K., Witlox, F., Yang, X., Basens, D., Shen, W. 2010: Measuring the World city network: new results and developments. Globalization and World cities 300. DOI: http://dx.doi.org/10.4018/978-1-60960-051-8.ch002

Taylor, P. J., Aranya, P. 2008: A global »urban roller coaster«? Connectivity changes in the World city network, 2000-04. Regional studies 42. DOI: http://dx.doi.org/10.1080/00343400601145202

Taylor, P. J., Catalano, G., Walker, D. R. F. 2002: Measurement of the World city network. Urban studies 39-1. DOI: http://dx.doi.org/10.1080/00420980220080011

Wall, R. S., Knaap van der, B. 2011: Sectoral differentiation and network structure within contemporary worldwide corporate networks. Economic geography 83-3. DOI: http://dx.doi.org/10.1111/ j.1944-8287.2011.01122.x

Wilczyński, W. J., Wilczyński, P. L. 2011: Population of American cities: 1950-2009. Bulletin of geography, Socio-economic series 16. DOI: http://dx.doi.org/10.2478/v10089-011-0020-y

Winiarczyk-Raźniak, A., Raźniak, P. 2012: Migracje wewnętrzne ludności w polskich obszarach metropolitalnych u progu XXI wieku. Kraków.

Winiarczyk-Raźniak, A., Raźniak, P. 2011: Regional differences In the standard of living in Poland (based on selected indices). Procedia - Social and behavioral sciences 19. DOI: http://dx.doi.org/10.1016/ j.sbspro.2011.05.103

Zioło, Z. 2006: Zróżnicowanie światowej przestrzeni przemysłowej w świetle koncentracji siedzib zarządów wiodących korporacji. Prace Komisji geografii przemysłu Polskiego Towarzystwa Geograficznego 8. 